\title{
Przyszłość to dziecinne mrzonki
}

\section{Lee Edelman}

Tufts University

[Od Redakcji] z przyjemnościa oddajemy w ręce czytelniczek i czytelników polski przekład fragmentu jednej z najbardziej wptywowych ksiażek z zakresu teorii queer w ostatnich latach, No Future: Queer Theory and the Death Drive autorstwa Lee Edelmana (2004, Durham-London: Duke University Press). The Future is Kid Stuff to pierwszy rozdziat tejże ksiażki (s. 1-32). Niniejszy przekład zostat opublikowany pierwotnie w: Teorie wywrotowe: antologia przekładów (2012, red. Agnieszka Gajewska, Poznań: Wydawnictwo Poznańskie, 675711). Przedruk za zgoda wydawcy.

Wiosną 1997 roku, jeszcze zanim prawicowe kręgi zdołały w końcu zadać bolesny cios prezydenturze Billa Clintona, znalazł się on w centrum pomniejszej, lecz mimo to wymownej, politycznej kontrowersji. Jego pojawienie się, u boku żony i córki, w serii ogłoszeń będących częścią kampanii społecznej, sponsorowanej przez organizację non-profit Ad Council, kazało - jak napisał "New York Times” - "zadać pytanie, gdzie kończy się polityka, a zaczyna służba społeczna”. Takie pytania przynajmniej dla tych, którzy je zadawali - odzwierciedlały obawę, że upowszechnianie wizerunku prezydenta w publikacjach prasowych i spotach telewizyjnych wyrażających poparcie dla grupy, która określała się jako Koalicja na rzecz Dzieci Ameryki, mogło przysporzyć mu popularności wśród wyborców, ponieważ wskazywało na jego przywiązanie do wartości ogólnie uznawanych za ponadpolityczne: wartości związanych z rodziną, rzecz jasna, lecz skupiających się zwłaszcza na ochronie dzieci. Ukazując prezydenta, by zacytować "Timesa", jako "zatroskanego i pracowitego rodzica”, jako osobę dbającą o dobro tych, którzy najmniej potrafią o siebie zadbać, a zwłaszcza jako "obrońcę dzieci w takich dziedzinach, jak edukacja i walka z narkotykami" - kampania dawała sporą szansę na polepszenie moralnego profilu Clintona w oczach opinii publicznej, a tym samym na zwiększenie jego poparcia wśród Amerykanów. Obawiał się tego przynajmniej Alex Castellanos, republikański konsultant ds. mediów, który narzekał na łamach Timesa: „Oto obraz ojca, dobrego ojczulka, głowy politycznego domu. Nic nie mogłoby działać bardziej na jego korzyść" (Bennet 1997).

Jednak tym, co najbardziej pomogło mu w tych publicznych apelach na rzecz dzieci Ameryki, był powszechny społeczny konsensus, że takich apeli nie można odrzucić. I choć publikacje w ramach kampanii kończyły się retorycznym gestem, kojarzonym z zaciętymi kampaniami politycznymi („Walczymy o dzieci. Po czyjej jesteś stronie?"), retoryka ta służyła w istocie zaświadczeniu, że w tej sprawie, tak jak na wstędze Möbiusa, dozwolona jest tylko jedna strona. Taka „oczywista” jednostronność - potwierdzenie wartości tak niekwestionowanej, ponieważ niemożliwej do zakwestionowania, jak wartość DZIECKA, którego niewinność domaga się od nas ochrony - niewątpliwie odróżnia ogłoszenia na rzecz dobra publicznego od partyjnego dyskursu argumentacji politycznej. Jednocześnie jednak twierdzę, że jest ona dokładnie tym, co czyni owe ogłoszenia bezwzględnie politycznymi: nie w partyjniackim sensie sugerowanym przez konsultanta ds. mediów, lecz w daleko bardziej podstępny sposób: politycznymi o tyle, o ile fantazmat podpierający obraz DZIECKA nieuchronnie kształtuje logikę, w ramach której musi być koncypowana polityczność jako taka. Ta logika 
zmusza nas, dopóki pretendujemy do politycznie odpowiedzialnego działania, abyśmy przyjęli ramy debaty politycznej - czy nawet samego pola polityczności - z góry określone przez to, co nazywam w tej książce reprodukcyjnym futuryzmem. Reprodukcyjny futuryzm narzuca na dyskurs polityczny ideologiczne granice, zachowując przy tym absolutne uprzywilejowanie heteronormatywności poprzez zanegowanie - wyrzucenie poza domenę polityczności - jakiejkolwiek możliwej do pomyślenia formy odmieńczego oporu wobec tej centralnej zasady organizującej relacje wspólnotowe.

Polityka, niezależnie od tego, jak radykalnych metod używa dana grupa, aby ustanowić bardziej pożądany porządek społeczny, pozostaje w gruncie rzeczy konserwatywnym przedsięwzięciem dopóty, dopóki działa na rzecz utwierdzenia pewnej struktury, uwierzytelniania porządku społecznego, który następnie zamierza przenieść w przyszłość w postaci swego wewnętrznego DZIECKA. To właśnie DZIECKO pozostaje stałym horyzontem każdej uznanej polityki, fantazmatycznym beneficjentem każdej politycznej interwencji. Nawet zwolenniczki i zwolennicy prawa do aborcji, popierający prawo kobiet do kontroli nad własnym ciałem poprzez możliwość decydowania o własnej rozrodczości, raz po raz przedstawiają swoją walkę polityczną jako „walkę o nasze dzieci - nasze córki i naszych synów", a więc walkę o przyszłość, w czym nie różnią się od swoich anty-aborcyjnych wrogów (Shalala 1998) ${ }^{1}$. Co w tej sytuacji mogłoby oznaczać nie „walczyć o dzieci”? Jak można opowiedzieć się po drugiej "stronie”, skoro opowiedzenie się po którejkolwiek stronie nieuchronnie zmusza nas do opowiedzenia się po stronie porządku politycznego (z racji pozostawania w jego wnętrzu), który powraca do DZIECKA jako figury zamierzonej przez siebie przyszłości? Nierealistycznie i wbrew zdrowemu rozsądkowi, mój projekt zgłasza pretensje do tej właśnie przestrzeni, którą „polityka” czyni niemożliwą do pomyślenia: do przestrzeni rozciągającej się poza ramami, w których pojawia się polityka, jaką znamy, a zatem poza konfliktem wizji, które łączy wspólne założenie, że ciało polityczna musi przetrwać. W centrum mojego zaangażowania w tekst kulturowy polityki oraz politykę tekstów kulturowych leży prosta, prowokacyjna teza, że odmieńczość (queerness) określa stronę tych, którzy nie "walczą o dzieci", stronę na zewnątrz konsensusu, zgodnie z którym wszelka polityka potwierdza absolutną wartość reprodukcyjnego futuryzmu. Obroty politycznej fortuny mierzą być może puls porządku społecznego, jednak odmieńczość, wykraczając poza sferę jego symptomów politycznych, odnosi się do miejsca popędu śmierci porządku społecznego. To, z całą pewnością, miejsce abiekcji wyrażonej poprzez piętno, niekiedy fatalne w skutkach, które jest efektem dosłownego odczytania tej figury, a więc miejsce, od którego liberalna polityka stara się - i stara się bardzo rozsądnie, zważywszy na jej nieograniczoną wiarę w rozum - odseparować queer. Idąc jeszcze dalej, staram się tu dowieść, że odmieńczość zyskuje walor etyczny o tyle tylko, o ile przyznaje się do tego miejsca, akceptując jego figuralny status jako miejsce oporu wobec żywotności organizmu społecznego i podkreślając nieodłączność takiego oporu od każdej struktury społecznej.

Aby dowieść powyższej tezy, w książce tej badam przykłady wszechobecnego powoływania się na DZIECKO jako symbol niekwestionowanej wartości przyszłości i w zamian proponuję niemożliwy projekt queerowej opozycyjności, który sprzeciwiałby się strukturalnym determinantom polityki jako takiej, a więc także samej logice opozycji. To paradoksalne sformułowanie sugeruje odmowę stosownie perwersyjną odmowę, która cechuje teorię queer - uznania jakiejkolwiek substancjalizacji

1 Warto też odnotować hasło namawiające do datków na rzecz National Abortion and Reproductive Rights Action League (NARAL): „Dla naszych córek, naszych sióstr i naszych wnuczek”. 
tożsamości, która jest zawsze definiowana przez opozycje², a w konsekwencji również odmowę uznania historii jako linearnej narracji (tej teleologii dla biedaków), w której znaczenie sukcesywnie ob.jawia się - jako znaczenie - z biegiem czasu. Nie uczestnicząc $w$ tym narracyjnym ruchu ku politycznie żywotnej przyszłości, daleki od podtrzymywania fantazji o ostatecznym urzeczywistnieniu się znaczenia, queer staje się figurą niemożności realizacji każdej wersji przyszłości, figurą oporu przynależnego temu, co społeczne - wobec każdej społecznej struktury lub formy.

Zamiast odrzucać, za dyskursem liberalnym, skojarzenie queeru z negatywnością, warto zastanowić się, czy nie lepiej je zaakceptować, czy wręcz się z nim utożsamić. Bynajmniej nie w nadziei na stworzenie doskonalszego porządku społecznego - taka nadzieja odtwarzałaby jedynie ograniczający mandat futuryzmu, podobnie jak każdy porządek w równym stopniu generowałby negatywność tego, co odmieńcze - ale raczej po to, by zanegować uporczywość samej nadziei jako afirmacji, która jest zawsze afirmacją pewnego porządku, podczas gdy jego negacja musi zostać odczytana jako niemożliwa do pomyślenia, nieodpowiedzialna, nieludzka. Co stanowi kartę przetargową afirmacji? Zawsze pytanie: jeśli nie to, to co? Zawsze żądanie, by przełożyć uporczywość, narzucającą się siłę, negatywności na określoną postawę lub „pozycję”, której dookreślenie jednocześnie by ją negowało: zawsze imperatyw, by uwięzić ją w jakiejś stabilnej i pozytywnej formie. A zatem kiedy twierdzę, że powinniśmy spróbować niemożliwego poprzez wymówienie naszej lojalności, mimo że obligatoryjnej, wobec rzeczywistości opartej na schemacie Ponziego reprodukcyjnego futuryzmu, nie mam zamiaru proponować jakiegoś "dobra", które zostanie tym samym zagwarantowane. Wręcz przeciwnie, zamierzam udowodnić, że nic, a na pewno nie to co zwykliśmy uznawać za "dobre”, nie może nigdy dawać jakiekolwiek gwarancji w porządku Symbolicznym. Rezygnując z wierności wobec futuryzmu, który i tak zawsze okupiony jest naszym kosztem, mimo iż pozostajemy skazani - jako Symboliczne podmioty wskazujące na demontaż Symbolicznego - na nieuniknioną sprzeczność zawartą w jego dążeniu do zaprzeczenia własnej czytelności, moglibyśmy raczej, metaforycznie, zagłosować na „żaden z powyższych", na prymat niezmiennego nie w odpowiedzi na prawo Symbolicznego, co imitowałoby akt założycielski tegoż prawa, jego samokonstytuującą się negację. Strukturalny optymizm polityki, na którą skazuje nas porządek znaczenia, instalując w nas nieustającą nadzieję na osiągnięcie znaczenia poprzez proces sygnifikacji, jest zawsze, ośmielam się twierdzić, negacją tego pierwotnego, konstytutywnego i negatywnego aktu. Rozmaite pozytywności wytwarzane w jego następstwie przez logikę politycznej nadziei, zasadzają się na matematycznej iluzji, że zanegowane negatywności mogą, w jakiś sposób wymknąć się takiej negatywności, zamiast ją dublować. A zatem losy mojej polemiki zależą od beznadziejnie niepewnego założenia, że uda się sprowadzić negatywność Symbolicznego do samej litery prawa; że uporczywe trwanie w rozumie czegoś niezbywalnego, z czym rozum się nie zgadza; że skierowanie mocy odmieńczości przeciwko wszelkim podmiotom, nawet queerowym, może nam otworzyć dostęp do jouissance, która jednocześnie nas definiuje i neguje. Albo lepiej: może to obnażyć stałość oraz nieuchronność dostępu do jouissance w samym porządku społecznym, nawet jeśli ów porządek ma dostęp do swego stałego dostępu do jouissance jedynie drogą abiektalnego projektowania owej stałości dostępu na odmieńczość.

2 Taki fantazmat zsubstancjalizowanych i opozycyjnych tożsamości charakteryzuje Lacanowski etap Wyobrażeniowy, w odróżnieniu od w pełni dyferencjalnego systemu sygnifikujących relacji w porządku Symbolicznym. 
W przeciwieństwie do tego, co Theodor Adorno opisywał jako „upór, z jakim człowiek trzyma się sam siebie jako czegoś bezpośrednio pewnego i substancjalnego", odmieńczość, o której mówię, świadomie oddzielałaby nas od nas samych, tj. od pewności, że znamy siebie i stąd wiemy, czym jest nasze "dobro" (Adorno 1986: 455-456). Zamiast dobra, odmieńczość taka proponuje coś, co chciałbym nazwać "lepszym", mimo że nie obiecuje absolutnie niczego, czy też: obiecuje absolutnie nic. Ideę tego czegoś lepszego łączę z Lacanowską charakterystyką tego, co nazywa on "prawdą", gdzie prawda nie zapewnia szczęścia ani nawet, jak daje do zrozumienia Lacan, dobra ${ }^{3}$. Zamiast tego prawda określa jedynie upartą jednostkowość podmiotu, niemożliwą do pełnego wyartykułowania i "skłaniającą się ku realnemu" (Lacan 1992: 24) ${ }^{4}$. Lacan może zatem napisać o tej prawdzie:

Cechą, która najlepiej ją charakteryzuje, jest to, że jest ona prawdziwym Pragnieniem [Wunsch], które leżało u podstaw anormalnego lub atypowego zachowania.

Napotykamy owo pragnienie, z jego szczególnym, nieredukowalnym charakterem, jako modyfikację, która nie zakłada żadnej innej formy normalizacji jak tylko doświadczenie przyjemności albo bólu, lecz doświadczenie ostateczne, z którego wyrasta, a następnie jest przechowywane w głębi podmiotu w nieredukowalnej formie. To pragnienie nie ma charakteru uniwersalnego prawa, lecz odwrotnie ma charakter najbardziej partykularnego z praw - nawet jeśli uniwersalnie odnajdujemy tę partykularność w każdym człowieku. (Lacan 1992: 24)

Prawda, tak jak odmieńczość, nieredukowalnie związana z „anormalnym lub atypowym”, czyli z czymś, co ściera się z "normalizacją", odnajduje swoją wartość nie w dobru poddającym się uogólnieniu, ale w upartej szczególności, która unika wszelkich konceptualizacji dobra ogólnego. Tak więc akceptacja queerowej negatywności może nie mieć żadnego uzasadnienia, jeśli uzasadnienie wymaga od niej potwierdzenia, jakiejś pozytywnej wartości społecznej; jej wartość tkwi natomiast w wyzwaniu, jakie rzuca definiowanej społecznie wartości, a w efekcie - w radykalnym wyzwaniu, jakie rzuca wartości społecznego w ogóle ${ }^{5}$.

Jako figura odrzucenia przymusowej wiary w najwyższą wartość przyszłości, przy jednoczesnym zaprzeczeniu nawracającej chyłkiem nadziei na dialektyczny dostęp do znaczenia, queer pozbawia porządek społeczny gruntu, na którym stoi: wiary w spójną realność społecznego, a co za tym idzie - w realność podmiotu społecznego; wiary, że polityka - czy to z prawa, czy z lewa - zawsze w domyśle afirmuje. Ogołacając tak rozumianą politykę z takiej lub innej tematycznej otoczki, biorąc w nawias partykularność jej różnych pomysłów na społeczną organizację, queer twierdzi, że

${ }^{3}$ W seminarium VII pisze na przykład: "Ce que la vérité, quand elle surgit, a de résolutif, ça peut être de temps en tempsheureux - et puis, dans d'autres cas, désastreux. On ne voit pas pourquoi la véritéserait forcément toujours bénéfique" (Lacan, 1991: 122).

4 "Je dis toujours la vérité: pas toute, parce que toute la dire, on n'y arrive pas. La dire toute, c'est impossible, matériellement: les mots y manquent. C'est même par cet impossible que la vérité tient au reel" (Lacan, 1974:9).

${ }^{5}$ W tym kontekście warto przytoczyć jeszcze jeden cytat z Dialektyki negatywnej Adorna: „Jeżeli dialektyka negatywna wymaga autorefleksji myślenia, to wynika stąd namacalnie, że myślenie, aby pozostało prawdziwe, w każdym razie dzisiaj, musi myśleć również przeciwko sobie. Jeżeli nie mierzy się ono tym, co najskrajniejsze, co umyka pojęciu, to z góry nabiera cech akompaniamentu, którym SS zwykła była zagłuszać krzyki swoich ofiar" (Adorno 1986: 512). 
polityka jest zawsze polityką znaczącego, albo nawet tego, co Lacan często nazywał "literą". Służy podtrzymywaniu rzeczywistości wiecznie niezakotwiczonej przez sygnifikację i pozbawionej jakichkolwiek gwarancji. Powiedziawszy to wszystko, nie zamierzam jednocześnie zaprzeczać istnieniu doświadczanej przemocy, która często zaburza rzeczywistość społeczną ani też pozornej spójności tej rzeczywistości, która nas podtrzymuje, a tym samym obciąża. Sugeruję raczej, że odmieńczość obnaża fałszywość naszej relacji z tym, czego doświadczamy w - i jako - rzeczywistości społecznej, pozwalając nam dostrzec fantazmaty strukturalnie niezbędne do jej utrzymania oraz dobierając się do owych fantazmatów od strony figuralnej logiki, struktur językowych, które je kształtują. Jeśli queer stawia sobie za cel skuteczną interwencję w reprodukcję takiej rzeczywistości - interwencję, którą równie dobrze może zobrazować jako aborcję owej rzeczywistości - wówczas musi nieustannie pamiętać o swoim związku ze zmiennymi losami znaku, z napięciem, jakie istnieje między redukcją znaczącego do trupiej materialności litery a jego udziałem w systemie referencjalnym, w którym generuje samo znaczenie. Innymi słowy, teoria queer jako szczególna opowieść o tym, dlaczego wszelkie snucie opowieści kończy się porażką, choć jednocześnie bierze na siebie wartość i ciężar tej porażki, w moim ujęciu, oznacza "drugą" stronę polityki - "stronę", po której narracyjne urealnienie zazębia się z odrealnieniem, gdzie życiodajne siły bezustannie zwracają się przeciwko sobie; "stronę” poza wszelkimi stronami w polityce, ponieważ niezależnie od strony wszystkie one angażują się po stronie niekwestionowanego dobra przyszłości. W pozostałej części tej książki staram się wyjaśnić implikacje wynikające z tego stwierdzenia, najpierw jednak naszkicuję szereg powiązań między polityką a polityką znaku, przybliżając psychoanalityczny kontekst, z którego wyrasta moja argumentacja.

Podobnie jak sieć sygnifikujących relacji, która tworzy Lacanowskie Symboliczne - rejestr mówiącego podmiotu i porządek prawa - polityka może funkcjonować jako ramy, w których doświadczamy rzeczywistości społecznej, ale tylko w takim stopniu, w jakim zmusza nas do doświadczania tej rzeczywistości w formie fantazmatu, a mówiąc ściślej: fantazmatu formy jako takiej, porządku, organizacji, który gwarantuje stabilność naszych tożsamości jako podmiotów oraz spójność Wyobrażeniowych totalizacji, dzięki którym tożsamości te jawią się nam w rozpoznawalnej formie. Jakkolwiek materialne warunki ludzkiego doświadczenia mogą istotnie być stawką w różnych konfliktach, poprzez które konkurujące perspektywy polityczne ubiegają się o prawo do nazywania, a poprzez nazywanie - kształtowania, naszej zbiorowej rzeczywistości, nieustający konflikt wizji społecznych zakrywa ich wspólne pragnienie, aby ustanowić - jako rzeczywistość samą w sobie - jeden libidinalnie podszyty fantazmat zamiast innego, w celu przesłonięcia pustki, którą znaczące umieszcza w samym sercu Symbolicznego. Inaczej mówiąc, polityka desygnuje obszar, w którym relacje Wyobrażeniowe, sięgające korzeniami błędnego rozpoznania siebie jako "ja", mającego jakiś pierwotny dostęp do obecności (obecności postulowanej retrospektywnie, a więc można rzec: utraconej od samego początku), konkurują między sobą o Symboliczne spełnienie, o urzeczywistnienie w obszarze języka, któremu upodmiotowienie podporządkowuje każdego z nas. Dopiero pośrednictwo znaczącego umożliwia nam artykulację owych Wyobrażeniowych relacji, jednak zawsze za cenę wprowadzenia dystansu, który wyklucza ich realizację: dystansu wpisanego w łańcuch niekończących się odroczeń i substytucji generowanych nieuchronnie przez język jako system różnic. Znaczące, jako alienująca i pozbawiona znaczenia oznaka Symbolicznego konstytuowania się naszej podmiotowości (tj. oznaka naszego upodmiotowienia poprzez poddanie się obietnicy znaczenia); znaczące, za sprawą którego zawsze zamieszkujemy porządek Innego, porządek społecznej i języ- 
kowej rzeczywistości, artykułowanej z innego miejsca; znaczące, które powołuje nas do znaczenia, choć zdaje się powoływać nas do bycia sobą: to znaczące nadaje nam jedynie rodzaj promisoryjnej tożsamości, takiej, z którą nigdy nie uda nam się uzyskać pełnej zbieżności, ponieważ, jako poddani znaczącego, sami możemy być jedynie znaczącymi, możemy jedynie aspirować do dorównania temu, co moglibyśmy oznaczać, gdyby udało nam się zlikwidować tę lukę, która nas rozdziela i która, paradoksalnie, czyni z nas podmioty właśnie poprzez sam akt rozdzielenia. Ta strukturalna niemożność zespolenia się podmiotu z "ja”, gdzie podmiot postrzega się jako znaczące dla "ja” w oczach Innego, rodzi potrzebę różnych strategii, które mają „pozszywać" [suture] podmiot w przestrzeni znaczenia, gdzie Symboliczne i Wyobrażeniowe na siebie zachodzą. Polityka odnosi się do społecznych działań, poprzez które podmiot usiłuje ustanowić warunki tej niemożliwej konsolidacji, identyfikując się z czymś na zewnątrz siebie, w celu osiągnięcia wiecznie odraczanej obecności siebie. A zatem polityka to nazwa dla dążenia do uskutecznienia fantazmatycznego porządku rzeczywistości, w którym alienacja podmiotu roztopiłaby się w bezszwowej tożsamości u kresu niekończącego się ciągu znaczących, przeżywanych jako historia.

Jeżeli polityka w ramach Symbolicznego jest zawsze polityką Symbolicznego, funkcjonującą w imię i w kierunku ustawicznie antycypowanej przyszłej rzeczywistości, to telos, który na poziomie fantazmatu zakończyłby wreszcie ciąg odroczeń, zapewniając tym samym obecność, ku której zawsze dąży metonimiczny łańcuch znaczących, należy uznać za przynależny Wyobrażeniowej przeszłości. Oznacza to nie tylko tyle, że polityka jest sprzężona z temporalnością pragnienia, czyli z jego nieuniknioną historycznością, połączoną z przemieszczaniem się afektywnych wiązań, które jako figury znaczenia stanowią miejsca intensywnych metaforycznych obsadzeń, i jako takie wytwarzane są w bezskutecznej nadziei na wypełnienie konstytutywnej dla podmiotu luki (spowodowanej przez pojawienie się znaczącego), ale także tyle, że polityka nazywa ową temporalizację pragnienia, przekładając ją na pewną narrację i jej teleologiczne dookreślenia. Polityka zatem, poprzez uzewnętrznienie w fikcyjnej formie opowieści tych libidinalnych naddeterminacji, alegoryzuje i sekwencyjnie rozwija - jako pewną formę pragnienia właśnie to, co tymczasem w samym Pragnieniu wiąże się z niespójnością psychicznych mechanizmów obronnych i zakłóceniem narracyjności, tj. z obecnością popędu, który nie daje się podporządkować ani logice interpretacji, ani wymogom samej produkcji znaczenia; popędu, którego destabilizująca siła, wynikająca z wykluczenia, napiera uporczywie spoza obszaru sygnifikacji.

Popęd, a ściślej popęd śmierci, zajmuje uprzywilejowane miejsce w tej książce. Jako nieustająca presja, obca, choć immanentna, logice Symbolicznego i jako niemożliwy do wyartykułowania nadmiar, który rozmontowuje podmiot od środka, popęd śmierci określa to, co w porządku społecznym mianowane jest odmieńczością, tj. figurę negatywności przeciwstawionej każdej formie społecznej żywotności. Lacan daje do zrozumienia, że popęd śmierci pojawia się jako konsekwencja Symbolicznego. Seminarium II skończył nawet twierdzeniem, że "porządek symboliczny jednocześnie nie istnieje i nalega, żeby istnieć; to właśnie ma na myśli Freud, kiedy mówi o instynkcie śmierci, że jest czymś najbardziej podstawowym - porządkiem symbolicznym w trakcie porodu, w procesie powstawania, nalegającym na swoje zaistnienie" (Lacan 1991: 326). Tego stałego ruchu ku realizacji nie można wszakże oddzielić od równoczesnego pragnienia, by rozmontować to, co się w tym procesie ustanawia, żeby znowu zacząć ex nihilo. Popęd śmierci wskazuje na nadmiar wbudowany w Symboliczne poprzez stratę, Realną stratę, którą powoduje nadejście znaczącego. Do- 
skonale ujmuje to Suzanne Bernard, wprowadzając rozróżnienie między podmiotem pragnienia a podmiotem popędu: „Podczas gdy podmiot popędu także »rodzi się« w relacji do straty, ta strata jest raczej realna niż symboliczna. Jako taka, funkcjonuje ona nie w trybie nieobecności, ale w trybie niemożliwego nadmiaru nawiedzającego rzeczywistość, nie dającej się stłumić pozostałości, od której podmiot nie może się odłączyć. Innymi słowy, o ile pragnienie rodzi się z konstytutywnego braku i jest przezeń podtrzymywane, o tyle popęd pojawia się w relacji do konstytutywnego nadmiaru. Nadmiar ten Lacan nazywa »anatomicznym dopełnieniem « podmiotu, »nierealną« pozostałością, która wytwarza zawsze obecną jouissance" (Barnard 2002: 173).

Ten nadmiar, zmuszający Symboliczne do nieustannego samopowtarzania, pozostaje widmowy, "nierealny" albo niemożliwy o tyle, o ile uparcie trwa poza logiką znaczenia, która - mimo to - wytwarza go. Popęd zajmuje miejsce tego, co znaczenie pomija, podobnie jak znaczące zachowuje w centrum porządku sygnifikacji pustą i arbitralną literę, pozbawione znaczenia podłoże sygnifikacji, które znaczenie stara się ukryć. Polityka stawiając się w opozycji do negatywności takiego popędu, daje nam historię jako nieustającą inscenizację naszego marzenia o ostatecznej samorealizacji, rekonstruując bez końca, w zwierciadle pragnienia to, co bierzemy za samą rzeczywistość. Czyni tak, nie pozwalając nam jednocześnie dostrzec, że przyszłość, do której nieustannie się odwołuje, oznacza niemożliwe miejsce Wyobrażeniowej przeszłości, wolnej od odroczeń wpisanych w działanie łańcucha sygnifikacji i projektowanej w przód jako miejsce, w którym byt i znaczenie są połączone w Jedność. Realizuje tym samym formalne powtórzenie specyficzne dla popędu, choć przedstawia się tak, jakby prowadziła do spełnienia narracyjnej sekwencji historii, a zarazem Pragnienia, poprzez urzeczywistnienie autentycznej obecności podmiotu w DZIECKU, któremu przypisuje się w wyobraźni możliwość bezpośredniego dostępu do Wyobrażeniowej pełni. Nic dziwnego, że era uniwersalnego podmiotu wytworzyła, jako centralną figurę polityki, a przy tym uosobienie przyszłości zlewającej się nierozstrzygalnie z przeszłością, obraz DZIECKA taki, jakim go znamy: DZIECKA, które staje się, słowami Wordswortha (lecz bardziej karząco), „ojcem Człowieka”. Konstruowane historycznie tak, aby mogło służyć jako magazyn różnie sentymentalizowanych identyfikacji, jak pokazali to historycy idei, m.in. Phillipe Ariès, James Kincaid i Lawrence Stone, DZIECKO stało się dla nas w końcu uosobieniem telosu porządku społecznego i tym, dla kogo należy ów porządek społeczny nieustannie pielęgnować6.

W efekcie swej obligatoryjnej uniwersalizacji obraz DZIECKA (nie mylić z faktycznym doświadczeniem historycznie żyjących dzieci) służy regulowaniu dyskursu politycznego - decydowaniu z góry, co w ogóle zalicza się do dyskursu politycznego - poprzez wymuszenie na tym dyskursie apriorycznej zgody na realność zbiorowej przyszłości, której figuratywnego statusu nigdy nie wolno nam rozpoznać ani komentować. Począwszy od ikonicznego przedstawienia na płótnie Delacroix Wolności, prowadzącej nas ku nowemu, wspaniałemu światu rewolucyjnych możliwości (na którym jej naga pierś, wystawiona niczym do karmienia, przemienia każdego widza we wciąż nieodstawione od piersi DZIECKO, podczas gdy chłopiec po jej lewej stronie, naśladując jej pozę, potwierdza absolutną logikę reprodukcji), po rewolucyjne dziecko ulicy na logotypie ilustrującym w miniaturze „politykę" musicalu Nędznicy (wyłożoną w "podnoszącym na duchu” hymnie na cześć futuryzmu, „Jeszcze dzień!"), nie potrafimy wyobrazić sobie polityki bez fantazmatu przyszłości, ani też przy-

${ }^{6}$ Zob. np. Ariès 2011; Stone 1977; Kincaid 1992 oraz 1998. 
szłości bez figury DZIECKA. Jedynie figuralne DZIECKO uosabia obywatela jako ideał zdolny żądać pełni praw do swego przyszłego udziału w narodowym dobru, choć zawsze kosztem ograniczenia praw przyznanych "realnym" obywatelom. Porządek społeczny istnieje po to, aby zachowywać dla tego zuniwersalizowanego podmiotu, tego fantazmatycznego DZIECKA, abstrakcyjną wolność cenioną wyżej niż wolność faktyczna, która może przecież zagrozić DZIECKU, któremu taka wolność przysługuje. Dlatego też wszystko, co podważa ów mandat, na mocy którego nasze instytucje polityczne wymuszają zbiorową reprodukcję DZIECKA, musi jawić się jako groźba już nie tylko dla organizacji danego porządku społecznego, ale również, daleko bardziej złowieszczo, dla porządku społecznego jako takiego, ponieważ zagraża logice futuryzmu, od której nieuchronnie zależy znaczenie.

Kiedy więc Phyllis D. James, w powieści Ludzkie dzieci, wyobraża sobie przyszłość, w której rodzaj ludzki zatracił - nieodwracalnie, jak się wydaje - zdolność rozmnażania się, jej narrator, Theodore Faron, nie tylko wini za to odwrócenie biologicznej fortuny domniemany kryzys wartości seksualnych w demokracjach drugiej połowy XX wieku - jak zauważa: „Pornografia i przemoc seksualna obecne w filmach, w telewizji, w książkach, w życiu wzrosły stały się bardziej dosadne, ale na Zachodzie kochaliśmy się coraz rzadziej i płodziliśmy coraz mniej dzieci" - ale także powtarza ideologiczny truizm, który rządzi naszą inwestycją w DZIECKO jako obligatoryjny emblemat przyszłości: „Bez nadziei na potomstwo, jeśli nie własne, to gatunku, bez pewności, że po naszej śmierci życie nie zaniknie [...] - czytamy dalej - wszystkie intelektualne i zmysłowe przyjemności czasami wydają się niczym więcej, jak żałosną, wąłłą obroną przed ostateczną zgubą" (James 2006:15, 17). Choć ta aluzja do Ziemi jałowej Eliota może przywołać inny znany wers poematu, który zawdzięczamy ponoć żonie Eliota, Vivian - „Po co wyszłaś za niego, jeśli nie chcesz dzieci?” (Eliot 1988: 85), jednocześnie uwypukla ona funkcję dziecka jako rekwizytu teologii sekularnej, na której opiera się nasza rzeczywistość społeczna; sekularnej teologii, która kształtuje zarówno znaczenie naszych zbiorowych narracji, jak i nasze zbiorowe narracje dotyczące znaczenia. Skoro DZIECKO ma za zadanie dopilnować, „żebyśmy, choć martwi, nadal żyli”, wydziela ono, jakby z natury (a ściślej mówiąc, jako obietnica naturalnego przekroczenia granic samej natury), tę samą żałość, przed którą narrator Ludzkich dzieci wzdraga się, kiedy natyka się na nią w nieprokreacyjnych „przyjemnościach intelektualnych i zmysłowych”. "Żałość”, którą projektuje na nierozrodcze rozkosze seksualne rozkosze, które wobec braku przyszłości uważa za puste, zastępcze, patologiczne - obnaża fetyszystyczne figuracje DZIECKA, które narrator przeciwstawia tamtym rozkoszom i które są czytelne dokładnie o tyle, o ile rozkosz bez "nadziei na potomstwo” zostaje bezdyskusyjnie odrzucona jako "żałosna, wątła obrona przed ostateczną zgubą". Czyż ten opis nie pasuje idealnie do całego narracyjnego schematu powieści Ludzkie dzieci, która kończy się, jak zapewne domyśla się od początku każdy, kto nie urodził się wczoraj, odnową naszej jałowej i umierającej rasy za sprawą cudu narodzin? W końcu, jak zauważa z aprobatą Walter Wangerin Jr., który zrecenzował książkę dla "New York Timesa", w zdaniu balansującym dyskretnie między opisem a zastosowaniem pro-prokreacyjnej ideologii powieści: „Jeśli jest dziecko, to jest przyszłość, jest ocalenie” (Wangerin 1993: 23). Jeśli jednak nie ma dziecka, a w konsekwencji nie ma przyszłości, wówczas wina musi spaść na fatalny urok bezpłodnych, narcystycznych rozkoszy, uważanych za z natury destrukcyjne dla znaczenia, a więc odpowiedzialne za likwidację organizacji społecznej, zbiorowej rzeczywistości oraz, nieuchronnie, samego życia. 
Zważywszy, że autorka Ludzkich dzieci, tak jak rodzice dzieci rodzaju ludzkiego, bez reszty ulega temu przemożnemu, bezkrytycznemu i strategicznie chybionemu narcyzmowi, który inspiruje pronatalizm ${ }^{7}$, nie zaskoczy nas chyba fakt, że w obliczu swojej bezprzyszłościowej przyszłości narrator z pełną powagą biada, że "seks zupełnie oddzielony od prokreacji staje się niemal bezsensowną akrobatyką" ${ }^{8}$. Oznacza to ni mniej, ni więcej, że uprawianie seksu będzie w dalszym ciągu alegorią zmiennych losów znaczenia, tak długo, jak długo specyficznie heteroseksualne alibi w postaci konieczności rozmnażania będzie zasłaniać ukryty poza znaczeniem popęd, napędzający maszynerię usensownienia seksu; czyli tak długo, jak długo biologiczny fakt heteroseksualnej prokreacji udziela heterogenitalnym relacjom, oficjalnej licencji na wytwarzanie znaczenia. DZIECKO jest bowiem figurą naszej identyfikacji z zawsze prawie-już-osiągniętą tożsamością; sama możliwość DZIECKA wystarcza, żeby naga prawda o heteroseksualnym seksie magicznie wyparowała, zapładniając - by tak rzec - heteroseksualność przyszłością sygnifikacji poprzez nałożenie na nią kulturowego ciężaru sygnifikacji przyszłości. Tym sposobem DZIECKO stawia odpór nieustannemu zagrożeniu dla społecznego porządku znaczenia, wbudowanemu w strukturę Symbolicznego Pragnienia, które skazuje nas na poszukiwanie spełnienia poprzez znaczenie, które - jako znaczenie - nie potrafi zapewnić nam spełnienia ani też samo się spełnić, ponieważ nie potrafi domknąć luki w tożsamości, tego dokonanego przez znaczące nacięcia, które „znaczenie”, wbrew sobie, oznacza.

Taka identyfikacja DZIECKA oraz z DZIECKIEM, które dobitnie reprezentuje motywujący cel, jakkolwiek zawsze odkładany na później, każdej politycznej wizji jako wizji przyszłości, musi mieć istotny wpływ na każdy projekt opozycyjnej polityki queer. Jedyna queerowość, jaką odmieńcze seksualności mogą mieć nadzieję sygnifikować, wypływałaby z ich stanowczej opozycji wobec tej fundamentalnej struktury polityczności, czyli z opozycji wobec dominującej fantazji osiągnięcia Symbolicznego domknięcia poprzez ożenienie tożsamości i przyszłości, gwoli spełnienia podmiotu społecznego. Konserwatyści rozumieją ten radykalny i zarazem radykalnie groźny potencjał queeru lepiej niż liberałowie, ponieważ konserwatyzm prewencyjnie wyobraża sobie całkowite rozerwanie materii społecznej, podczas gdy liberalizm pielęgnuje konserwatywną wiarę w swoją bezgraniczną elastyczność. Dyskurs prawicowy skłania się ku wyraźniejszemu rozpoznaniu i podkreślaniu literalizacji figuralnej logiki, którą różne podmioty społeczne są zmuszone zamieszkiwać i odgrywać, logiki redukującej - z "racjonalnego" punktu widzenia - indywidualną tożsamość do stereotypowej ogólności, podczas gdy dyskurs lewicowy lepiej rozumie zdolność Symbolicznego do przyswojenia zmiany, dzięki przeniesieniu tej logiki na historię jako nieuniknione rozwijanie się narracyjnej sekwencji. Prawica lepiej dostrzega nieuniknienie konfliktualny aspekt tożsamości, stan ich nieustannego zagrożenia w obliczu inności, wewnętrzny niepokój, jaki towarzyszy ich podtrzymywaniu, natomiast lewica jest bardziej świadoma tego, w jaki sposób historia ustawicznie przepisuje owe

\footnotetext{
7 Już słyszę te okrzyki: „Toż to narcyzm! Któż, jak nie rodzic, jest bardziej skłonny do ofiar i wyrzeczeń? Któż chętny wykonywać szereg czasochłonnych prac bez wynagrodzenia?". Bez wynagrodzenia? Sprawdźcie lepiej saldo społecznej aprobaty. Ulgi podatkowe, zniżki dla dzieci, różnego typu urlopy rodzicielskie: wszystkie te rzeczy bledną, rzecz jasna, w obliczu kosztów wychowania dziecka. Ale zysków z pronatalizmu nie należy mierzyć głównie w dolarach czy w walucie zdrowego rozsądku. Są one wliczone w powszechne poświadczenie twojej dorosłości oraz w przyrost społecznego kapitału, który zezwala ci na udział w jedynym rynku przyszłości, który naprawdę się liczy.

8 "Można by mniemać, że wolny od wyeliminowanego na stałe lęku przed ciążą i mało erotycznej otoczki pigułek, gumek czy arytmetyki owulacji, seks stanie się dziedziną nowych, pomysłowych rozkoszy. Stało się na odwrót. Nawet tym mężczyznom i kobietom, którzy w normalnych okolicznościach nie chcieliby się rozmnażać, najwyraźniej brakuje pewności, że mogliby mieć dziecko, gdyby go pragnęli" (James 2006: 138).
} 
tożsamości, czerpiąc nadzieję z faktu, że granice tożsamości nie są nigdy ustalone raz na zawsze. Tak więc lewica ma zawsze rację z punktu widzenia rozumu, jednak w cieniu tego rozumu kryje się ciemność nieodłączna od jego światła: obronna struktura ego, skostniałość tożsamości, tak jak doświadcza jej podmiot, oraz sztywność Wyobrażeniowej relacji, przez którą się (re)produkujemy. Ten konserwatyzm ego zmusza podmiot, czy to konserwatywny, czy liberalny politycznie, do uznania za sens polityki jako takiej, reprodukcyjnego futuryzmu, który utrwala, jako rzeczywistość, fantazmatyczną konstrukcję mającą na celu zapewnienie przetrwania tego, co społeczne, w Wyobrażeniowej postaci DZIECKA.

Rozważmy na przykład lokalny epizod obecnej wojny przeciwko aborcji. Nie tak dawno temu, w pewnym ruchliwym miejscu miasta Cambridge, Massachusetts, przeciwnicy prawa do aborcji wynajęli billboard, na którym umieścili wizerunek zaawansowanego płodu, powiększonego do rozmiarów przerastających dorosłego człowieka, z napisem "To nie jest wybór, to jest dziecko". Barbara Johnson w swojej błyskotliwej analizie podobnych antyaborcyjnych wystąpień, pokazała, w jaki sposób wykorzystują one i tworzą skutecznie oddziałujące tropy, oparte na personifikacji płodu, które z góry przesądzają odpowiedź na prawnicze pytanie o jego osobowy status, determinując, w jakich kategoriach należy rozpatrywać płód, a więc także związaną z nim kwestię prawną (Johnson 1997: 184-199). Zamiast dekonstruować ten konkretny retoryczny przykład (tj. zamiast odnotować zestawienie właściwego dla płodu zaimka „to”, z wysoce uczłowieczającym epitetem "dziecko”, który domagałby się raczej zaimka rodzaju męskiego albo żeńskiego, w celu pokazania, jak ten fragment dyskursu podtrzymuje nierozstrzygalność, którą chciałby przezwyciężyć, czyli zamiast podać w wątpliwość prawdziwość tego stwierdzenia za pomocą formy wypowiedzi), wolę skupić się przez moment na ideologicznej prawdzie, którą ta wypowiedź, być może niechcący, uwidacznia.

Jakkolwiek dziwnie zabrzmi to w ustach geja, kiedy pierwszy raz ujrzałem wspomniany billboard w Cambridge, uznałem, że jest adresowany do mnie. Przecież ów znak mógłby równie dobrze głosić, z tą samą absolutną i niewidzialną autorytatywnością świadczącą o udanej pracy ideologicznej naturalizacji, biblijny nakaz „Bądźcie płodni i mnóżcie się!” Tak jak zniekształcony anamorfotycznie obraz, który zyskuje rozpoznawalną formę dopiero wówczas, gdy spojrzy się nań pod odpowiednim kątem, tak tamten slogan - poprzez moją subiektywnie "wykrzywioną" z nim relację nabrał logicznego sensu, który rzucił światło na wspólne podłoże sprzeciwu, wojującej prawicy wobec aborcji i odmieńczych praktyk seksualnych - wspólne podłoże aż za dobrze znane (jako dosłowne potraktowanie figuralnej tożsamości) takim radykalnym grupom, jak Armia Boga (Army of God), która wzięła na siebie odpowiedzialność za terrorystyczne ataki bombowe na klinikę aborcyjną oraz na klub nocny uczęszczany przez lesbijki i gejów w stanie Atlanta w 1997 roku. Billboard z Cambridge zdawał się oznajmiać to, co liberalizm woli ukrywać, a mianowicie, że naczelnym przymusem, szczególnym nakazem, który nie pozostawia nam żadnego sensownego wyboru, jest przymus afirmacji naszej własnej przyszłości w uprzywilejowanej postaci DZIECKA, przymus postrzegania każdej chwili jako brzemiennej DZIECKIEM naszych Wyobrażeniowych identyfikacji, brzemiennej znaczeniem, którego obecność zapełniłaby dziurę w Symbolicznym, dziurę, która wskazuje zarówno miejsce Realnego, jak i wewnętrzny podział albo dystans, który konstytuuje nas jako podmioty i skazuje na podążanie za fantomem znaczenia poprzez metonimiczne osuwanie się znaczącego. 
Z tego powodu lewica wzdraga się przed utożsamieniem z aborcją nie mniej niż prawica; zamiast tego staje po stronie "wyboru”, jak szyderczo głosi billboard. No bo któż chciałby opowiedzieć się za aborcją, czyli przeciwko rozmnażaniu, przeciwko przyszłości, a zatem przeciwko życiu? Kto chciałby zniszczyć DZIECKO, a wraz z nim życiodajną fantazję zniesienia sygnifikacyjnej luki (fantazję, która odwraca naszą uwagę od przemocy popędów, pozwalając nam jednocześnie je odgrywać)? I znowu prawica zna odpowiedź, wie, że prawdziwie opozycyjna polityka implikowana przez odmieńcze praktyki seksualne, leży nie w dyskursie liberalnym i cierpliwym negocjowaniu tolerancji i praw, choć niewątpliwie pozostają one ważne dla tych wszystkich z nas, którym się ich odmawia, ale w fakcie, że odmieńcze seksualności mają możliwość stać się figurą radykalnego zerwania kontraktu, w każdym społecznym i Symbolicznym sensie, na którym opiera się przyszłość jako domniemana osłona przeciwko jouissance Realnego. Z tą wiedzą powinniśmy śledzić odczytania odmieńczych seksualności, produkowane przez siły reakcji, a może nawet się od nich uczyć. Jakkolwiek pragnęlibyśmy odwrócić system wartości, leżący u podstaw poniższej wypowiedzi Donalda Wildmona, założyciela i lidera homofobicznej organizacji American Family Association, warto odczytać ją nie tyle jako przykład nadętej tyrady, ile raczej jako przywołanie dezorientacji, jaką odmieńcze seksualności powinny wywoływać: „Aprobata dla albo obojętność wobec ruchu homoseksualnego doprowadzi do zniszczenia społeczeństwa, dając przyzwolenie na redefinicję porządku cywilnego i strącając nas, nasze dzieci i wnuki, w otchłań bezbożności. Zagrożone są same fundamenty zachodniej cywilizacji" (Wildmon 1997). Zanim z naszych ust posypią się pełne moralnego zadęcia komunały rodem z liberalnego pluralizmu, zanim padnie zapewnienie, że nasza miłość jest wprawdzie inna, ale to przecież miłość, zanim wygłosimy nabożnie litanię o naszym wkładzie w cywilizacje Wschodu oraz Zachodu, czy odważamy się zatrzymać na moment i przyznać, że pan Wildmon może, albo jeszcze lepiej - powinien mieć rację: że odmieńczość powinna i musi zredefiniować takie pojęcia jak "porządek cywilny” poprzez odcięcie się od naszej fundamentalnej wiary w reprodukcję przyszłości?

To prawda, że zastępy lesbijskich, gejowskich, transseksualnych i transpłciowych rodziców rosną z dnia na dzień i że nic rdzennie konstytutywnego dla osób identyfikujących się jako lesbijki, geje, osoby transseksualne, transpłciowe czy queer nie predysponuje ich do tego, aby odżegnywać się od przyszłości, opierać się pokusie prokreacji albo stawiać się poza akulturacyjną logiką Symbolicznego, tudzież w opozycji do niej. Co więcej, nie ma na zewnątrz tej logiki żadnego gruntu, na którym moglibyśmy stanąć. Promując alternatywę dla linii partyjnej, popieranej przez każdą partię, stawiając się na zewnątrz logiki reprodukcyjnego futuryzmu i przekonując, że odmieńcy mogliby pogodzić się z faktem, że są figuralnie kojarzeni z jego końcem, ani przez chwilę nie zakładam, że odmieńcy - przez co rozumiem wszystkich napiętnowanych tym określeniem, ponieważ nie przestrzegają heteronormatywnych nakazów - nie inwestują psychicznie w zachowanie dobrze znanej, familijnej narracji reprodukcyjnego futuryzmu ${ }^{9}$. Jednak polityka, opozycyjna czy nie, nigdy nie opiera

9 Przywołajmy w tym miejscu kontrowersje spowodowane wypowiedzią senatora Ricka Santoruma dla Associated Press w kwietniu 2003 r., w której powiązał homoseksualizm z bigamią, kazirodztwem i zagrożeniem dla rodziny. Polemiczny komentarz w "New York Timesie" potrafił jedynie odpierać twierdzenia Santoruma, przywołując dyskurs wartości rodzinnych i reprodukcyjnego futuryzmu: „Ale geje i lesbijki to więcej niż synowie i córki. Jesteśmy również matkami i ojcami. Wraz z partnerem adoptowaliśmy pięć lat temu syna i planujemy ponowną adopcję. w miarę jak coraz więcej par jednopłciowych będzie zakładać rodziny, republikanom pokroju pana Santoruma coraz trudniej będzie używać argumentu, że stanowimy jakieś zagrożenie dla amerykańskiej rodziny" (G.O.P. Hypocrisy, 2003: A33). 
się na esencjalnych tożsamościach. Zamiast tego skupia się na figuralności, która jest dla tożsamości nieodzowna, a przez to na figuralnych relacjach, w które społeczne tożsamości są zawsze wpisane.

Być figura demontażu społeczeństwa cywilnego, figurą popędu śmierci obowiązującego porządku, nie oznacza bynajmniej być albo stawać się tym popędem; takie "bycie" nie ma tu nic do rzeczy. Przyjęcie tej figuralnej pozycji charakteryzuje raczej rozpoznanie, w jaki sposób rzeczywistość jest fundowana na zaprzeczeniu popędu śmierci, oraz odrzucenie wynikających z tego faktu konsekwencji. Tak jak popęd śmierci rozpuszcza skrzepłe tożsamości, które pozwalają nam znać się i trwać jako "ja", tak queer musi dążyć do zakłócania, queerowania, organizacji społecznej jako takiej - czyli do zakłócania i queerowania nas samych i naszych inwestycji w tę organizację. Odmieńczość nie może bowiem nigdy definiować tożsamości, może ją jedynie zakłócać. Kiedy więc dowodzę w moich rozważaniach, że ciężar odmieńczości należy lokować nie tyle w afirmacji opozycyjnej tożsamości politycznej, ile w opozycji do polityki rozumianej jako nadrzędny fantazmat spełnienia się, w nieokreślonej przyszłości, Wyobrażeniowych tożsamości, od których odcięło nas nasze konstytutywne poddanie się znaczącemu, nie proponuję żadnego programu ani żadnej pozycji, z której odmieńcza seksualność czy jakikolwiek queerowy podmiot mogłyby ostatecznie stać się sobą, tak jakby możliwe było tym sposobem osiągnięcie jakiejś esencjalnej odmieńczości ${ }^{10}$. Sugeruję natomiast, że skuteczność queeru, jego strategiczna wartość, tkwi w oporze wobec Symbolicznej rzeczywistości, która inwestuje w nas jako podmioty o tyle tylko, o ile sami się w nią inwestujemy, trzymając się kurczowo jej nadrzędnych fikcji, jej uporczywych sublimacji, niczym samej rzeczywistości. W końcu tylko jej figurom znaczenia, które bierzemy za dosłowną prawdę, zawdzięczamy nasze istnienie jako podmiotom oraz relacje społeczne, w których żyjemy - relacje, za podtrzymanie których możemy nawet być gotowi oddać życie.

DZIECKO w historycznej epoce naszego obecnego reżimu epistemologicznego, stanowi figurę tej obowiązkowej inwestycji w błędne rozpoznanie figury. Dokonuje się ona na społecznej scenie na podobieństwo musicalowej Annie, która sięga do swych bezgranicznych funduszy dzielności, po to by "wysunąć do przodu brodę / Uśmiechnąć się szeroko / i rzec: "Jutro! / Jutro! / Kocham Cię / Jutro / Jesteś zawsze / o jeden dzień przed nami «" (Charnin 1977). I oto zaiste, widziana przez pryzmat łez, które przecież zawsze wywołuje, figura DZIECKA migoce wielobarwną obietnicą tęczy Noego, przypieczętowując - tak jak i ona - przymierze, które osłania nas przed nieustanną groźbą apokalipsy teraz albo później. Przypomnijmy sobie zakończenie Filadelfii (1993) Jonathana

10 Pisząc książkę taką, jak ta, należy być przygotowanym na różnego rodzaju opór. I tak niektórzy odrzucą, z „polityczną" zadziornością to, co odczytają jako „apolityczny” formalizm, niedostatecznie „uhistorycznioną" interwencję w materialność polityki tu i teraz. Fakt, że takie wersje polityki i historii reprezentują obowiązkową normę, którą moja książka ma na celu podważyć, nie powstrzyma, rzecz jasna, ich orędowników przed utwierdzaniem się we własnym deklarowanym "radykalizmie". Jednym z wariantów tej postawy będzie atak na burżuazyjny przywilej (różnie opisywany, w kategoriach tożsamościowych, jako "biały”, „klasy średniej”, "akademicki”, czy - w najbardziej znamiennej wersji - "gejowski”), który zdaniem niektórych - determinuje mój argument. Fakt, że wśród zwolenników takiej krytyki wielu będzie "białymi / akademikami / z klasy średniej” i - zapewne w niejednym wypadku - „gejami”, nie zmąci łatwości, z jaką będą konstatować tego rodzaju „zdeterminowanie”. Mam nieco więcej sympatii dla tych, którzy będą skłonni zdyskwalifikować książkę za jej język (który nazwą żargonem), za jej podstawy teoretyczne (które uznają za elitarystyczne), za jej nieprzystępność (którą będą postrzegać jako pretensjonalność), lub za jej styl (który wyda im się zawiły). Takie zarzuty mają przynajmniej tę zaletę, że odnotowują frustrację pragnienia w obliczu tego, co doświadczane jest jako nadobecność popędu. Jednak mimo "nieco większej" sympatii dla takich reakcji, jej zasoby - przyznaję - i w tym przypadku pozostają ograniczone. 
Demme'a, jego filmowy akt skruchy za homofobiczność przypisywaną przez niektórych Milczeniu owiec (1991). Po tym, jak Andrew Beckett (człowiek rozlicznych zalet, w kreacji świątobliwego Toma Hanksa) widziany po raz ostatni na łożu śmierci w masce tlenowej, która zdaje się nawiązywać do bardziej pamiętnego kagańca Hannibala Lectera, porzuca ziemski padół, aby stanąć, jak to się sugeruje, przed wyższym trybunałem, podążający jego śladem widz ogląda pokój w jego domu rodzinnym, wypełniony dziećmi i kobietami w ciąży, których wypukłe brzuchy wypierają wypukłe genitalia (niewidoczne) seropozytywnego geja (niewidocznego), od którego, jak sugeruje tekst filmu, w kinie niebojącym się odważnych przedstawień męsko-męskiego seksu (inaczej niż w kinie, w którym oglądamy Filadelfię), święty Tomasz Becket zaraził się wirusem, który kosztował go utratę życia. Kiedy więc, w końcowej sekwencji, widzimy zarejestrowaną na taśmie wideo zabawę małego Andrew na plaży, łzy, które te poruszające obrazy wyciskają z oczu, wyrażają oburzenie nie tylko na nietolerancyjny świat, który starał się stłamsić tego szlachetnego mężczyznę, na jakiego miał później wyrosnąć ów mały chłopiec, ale także na homoseksualny świat, w którym chłopcy tacy jak on wyrastają w końcu na mężczyzn, ulegających urokowi innych mężczyzn. Kult DZIECKA nie dopuszcza sanktuariów dla odmieńczości dziewczynek i chłopców, jako że we współczesnej kulturze w ogólności, a w Filadelfii w szczególności, odmieńczość z założenia oznacza koniec dzieci i dzieciństwa. Tym sposobem śmierć geja daje filmowi okazję, aby po raz kolejny przywołać dyscyplinujący wizerunek "niewinnego" DZIECKA, wykonującego swoją obowiązkową pracę reprodukcji społecznej. Ten wizerunek otacza nas z każdej strony, gdy tymczasem dorośli muszą liczyć się nieustannie z groźbą prawnej ingerencji w swoje życie, w wolność słowa i inne swobody, ingerencji dokonywanej w imię wyimaginowanych DZIECl, których przyszłość - jak gdyby mogły one mieć jakąkolwiek przyszłość inną niż perspektywa przekazania jej dalej swoim własnym DZIECIOM - jest rzekomo zagrożona społeczną chorobą, reprezentowaną przez odmieńcze seksualności. Nie powinniśmy też zapominać, do jakiego stopnia AIDS (nota bene najskuteczniejsza jak dotąd kampania o przyznanie przez Kongres funduszy na leczenie osób chorych na AIDS, związana jest z imieniem dziecka, Ryana White'a) wpisuje się w starszą tradycję, tak starą jak antyhomoseksualne odczytanie narzucone biblijnej opowieści o zniszczeniu Sodomy, łączącą praktyki homoseksualne z końcem przyszłości ${ }^{11}$. Właśnie to skojarzenie wykorzystała zmyślnie Anita Bryant, prowadząc kampanię przeciwko przyznaniu praw obywatelskich osobom homoseksualnym na Florydzie pod hasłem "Ratujmy nasze dzieci!” („Save Our Children!”); na nim bazuje też narodowa krucjata przeciwko homoseksualnym małżeństwom.

Podczas gdy tysiące lesbijek i gejów działa na rzecz prawa do małżeństw jednopłciowych, prawa do służby w wojsku, do wychowywania własnych i adoptowanych dzieci, prawica przeciwstawia się tym wysiłkom, każąc nam uklęknąć przed sanktuarium świętego DZIECKA; DZIECKA, które mogłoby stać się świadkiem lubieżnych lub niewłaściwych zachowań intymnych; które mogłoby znaleźć informacje o "niebezpiecznych" stylach życia w Internecie; które mogłoby sięgnąć po prowokacyjną książkę w publicznej bibliotece; jednym słowem DZIECKA, które mogłoby odkryć taki rodzaj przyjemności, który anulowałby narzuconą przez dorosłe pragnienie figuralną wartość DZIECKA jako nienaznaczonego profanującym uwikłaniem dorosłego w pragnienie; a zatem DZIECKA, które ma obrazować, gwoli satysfakcji dorosłych, Wyobrażeniową pełnię pozbawioną wszelkiego braku, a więc wszelkiego pragnienia. Jak przekonująco dowodzi Lauren Berlant na początku książki The Queen of

11 Zob. Sedgwick 1990: 128. 
America Goes to Washington City, "naród stworzony dla dorosłych obywateli został zastąpiony wyimaginowanym narodem dla płodów i dzieci" (Berlant 1997: 1). Nasza wolność jest ograniczana z każdej strony przez wydłużający się cień DZIECKA, a jego prawo do rozwoju niezakłócanego przez kontakt, czy nawet samą możliwość kontaktu, z „innością", której nie akceptują jego rodzice, Kościół albo państwo, do rozwoju nienarażonego na potencjalny dostęp do tego, co odmalowywane jest jako obca forma pragnienia, terroryzuje nas i utrzymuje w ryzach, sprawiając, że dyskurs polityczny przestrzega narracyjnej logiki, zgodnie z którą historia postępuje naprzód jako przyszłość zaplanowana dla DZIECKA, któremu nie wolno nigdy dorosnąć. Nie bez kozery historyczne konstruowanie homoseksualisty jako osobnego typu społecznego, zbiegło się w czasie z pojawieniem się takich postaci literackich, jak Mały Tim, David Balfour i Piotruś Pan, które wyrażają (zgodnie z imperatywem najlepiej dziś widocznym w niepokojąco bliskim powiązaniu Harry'ego Pottera z Voldemortem) Symboliczny opór wobec nieżonatych mężczyzn (Scrooge'a, Wujka Ebenezera, kapitana Hooka), będących uosobieniem, jak świadczy o tym imię Voldemorta ${ }^{12}$, życzenia, woli albo popędu śmierci, a w konsekwencji zniszczenia DZIECKA. Zamknięte w twierdzy niewinności, znajdującej się rzekomo pod nieustannym obstrzałem, DZIECKO odzwierciedla w skondensowanej formie stan narażenia na odmieńczość odmieńczych seksualności dokładnie w takim samym stopniu, w jakim uświęca ono, w formie swojej sublimacji, wartość, za którą sama odmieńczość jest tak często potępiana: obstawanie przy tym samym w imię odzyskania Wyobrażeniowej przeszłości. DZIECKO jest więc znakiem fetyszystycznej fiksacji heteronormatywności, polegającej na erotycznie naładowanej inwestycji w sztywną to-samość tożsamości, która ma kluczowe znaczenie dla obowiązkowej narracji reprodukcyjnego futuryzmu. Tak jak utrzymuje radykalna prawica, batalia przeciwko odmieńcom jest walką na śmierć i życie o przyszłość DZIECKA, do zniszczenia którego chcą doprowadzić feministki, odmieńcy oraz zwolennicy prawnej dopuszczalności aborcji. Instrukcja budowy bomby przygotowana przez Armię Boga dla swoich walczących „w obronie życia” członków, jasno dowodzi, że cele tej organizacji są w pełni zbieżne z logiką reprodukcyjnego futuryzmu: „osłabić, a ostatecznie zniszczyć moc Szatana, która pozwala mu zabijać nasze dzieci, dzieci Boga"13.

Nie rezygnując z obnażania kłamstw przepełniających te dobrze nam znane prawicowe diatryby, czy zdobędziemy się równocześnie na odwagę, żeby uznać, albo wręcz poprzeć, powiązane z nimi prawdy? Czy stać nas na wystarczającą opozycyjność względem strukturalnej logiki opozycji, tj. względem logiki, na mocy której polityka reprodukuje naszą społeczną rzeczywistość, aby pogodzić się z myślą, że figuralne brzemię odmieńczości, będące efektem fobicznej produkcji odmieńczości jako reprezentacji owego brzemienia, to w istocie siła rozsadzająca fantazję Wyobrażeniowej jedności, siła nie dająca zapomnieć o pustce (wypełnionej, paradoksalnie, jouissance) nieodzownie wbudowanej w symbolizację, choć od niej odgrodzonej, o luce albo ranie Realnego, ulokowanej w samym sercu Symbolicznego? Nie żebyśmy stali, albo mogli kiedykolwiek stanąć, na zewnątrz Symbolicznego; możemy jednak dobrowolnie zgodzić się na kulturową produkcję nas samych - wewnątrz dominującej logiki narracyjnej, wewnątrz rzeczywistości ustanowionej przez Symboliczne - jako figur likwidacji tej logiki, a więc figur popędu śmierci, który się w niej kryje.

12 Pierwsza część złożenia - „vol-" - odwołuje się zapewne do łacińskiego volo - "chcieć, pragnąć”, druga natomiast do łaciskiego mors/mortis - "śmierć" (z wyrazów tych wywodzi się szereg wyrazów pochodnych wjęzykach romańskich, a także w angielskim). Jako złożenie romańskich tematów wyrazowych, imię "Vol-de-mort" można odczytywać dosłownie jako „wola śmierci”. [Przyp. tłum.]

${ }^{13}$ Cyt. przez Sack 1997: A13. 
Jako nazwa dla siły mechanicznej kompulsji, której formalny nadmiar zajmuje miejsce każdego celu, na który mogłaby się ona wydawać skierowana, popęd śmierci nie godzi się na tożsamość ani na absolutne uprzywilejowanie jakiegokolwiek celu. Taki cel, taki punkt dojścia, nigdy nie okaże się "tym"; raz osiągnięty, nigdy nie zapewni zaspokojenia. Popęd jako taki może jedynie uparcie trwać, a każdy cel, jaki będziemy błędnie przypisywać jego trwaniu, jest zaledwie gramatycznym znakiemwypełniaczem, który każe nam odczytywać jako przechodnie owo parcie, które samym swoim upartym trwaniem osiąga zaspokojenie, jakiego nie jest w stanie zapewnić żaden cel. Krążąc wokół obiektu, który nigdy nie da mu zaspokojenia, popęd realizuje się w powtórzeniu, charakteryzującym to, co Judith Butler nazwała "repetytywnym napędem seksualności” (Butler 1993: 62). Za strukturalny mandat popędu można zatem uznać powoływanie do życia obiektu albo celu, a nawet więcej: całego rejestru seksualności, jako przeniesienia jego własnej energii formalnej, jako alegoryzację jego dyferencjalnej siły. Jednak tej siły nie da się pomyśleć w oderwaniu od (albo przed powstaniem) Symbolicznego porządku znaczącego, który stara się ona przekraczać. To dlatego Lacan argumentuje, że "jeśli wszystko, co jest immanentne lub implicytne w łańcuchu naturalnych zdarzeń, można uznać za podlegające tzw. popędowi śmierci, to tylko dlatego, że istnieje łańcuch sygnifikacji" (Lacan 1992: 212).

Jednym ze sposobów podejścia do popędu śmierci w kategoriach ekonomii tego „łańcucha naturalnych zdarzeń", uformowanego przez struktury językowe - struktury pozwalające nam wytwarzać owe „zdarzenia” za pomocą logiki narracyjnej historii - jest odczytywanie miejsca i działania popędu śmierci w odniesieniu do teorii ironii, tej najbardziej queerowej ze wszystkich figur retorycznych, zwłaszcza w ujęciu Paula de Mana. Postawiwszy tezę, że „każda teoria ironii jest unieważnieniem, koniecznym unieważnieniem, każdej teorii narracji", de Man powołuje się na stałe napięcie pomiędzy ironią jako konkretnym tropem, a narracją jako sposobem reprezentacji alegoryzującym tropy w ogólności. Narracja podejmuje się zadania systematyzacji tropu, dokonując - jak powiada de Man w nawiązaniu do Schlegela - „anamorfozy tropów, transformacji tropów, w całościowy system tropów, czemu odpowiada doświadczenie "ja" stawiającego się ponad własnym doświadczeniem". Natomiast ironia, jak stwierdza de Man, „zakłóca (według Friedricha Schlegela) tę właśnie dialektykę i refleksyjność". Korodujące działanie ironii u de Mana jest zatem bliskie działaniu popędu śmierci u Lacana. „Słowa potrafią mówić rzeczy zupełnie różne od tego, co chcielibyśmy, aby mówiły”, zauważa de Man. „Jest tu maszyna, tekstowa maszyna, nieustępliwa determinacja i całkowita arbitralność [...], która zamieszkuje słowa na poziomie gry znaczącego, która rozbija jakąkolwiek narracyjną spoistość linii, rozbija refleksyjny i dialektyczny model, będące, jak wiadomo, podstawą każdej narracji" (Man de 1996: 179, 181). Bezmyślna przemoc tej tekstualnej maszyny, tak arbitralna, tak nieustępliwa, że grozi, niczym gilotyna, odcięciem genealogii, którą narracyjna składnia tak bardzo stara się utwierdzić, przez co narracyjny "łańcuch [...] wydarzeń" zamienia się w "łańcuch sygnifikacji", a w przestrzeń sygnifikacji wpisana zostaje, wraz z obietnicą znaczenia, pozbawiona znaczenia maszyneria znaczącego, nieodmiennie stająca na drodze ku temu, co miałaby oznaczać. Ironia, której efekt de Man porównuje do składniowej przemocy anakolutu, przerywa ciągłość nieodzowną do produkowania sensu.

Jak odczytywać to nieustanne zakłócanie narracyjnej sygnifikacji, zakłócanie nieodłączne od artykulacji narracji jako takiej, jeśli nie jako jedną z wersji popędu śmierci, który Barbara Johnson nazywa w innym kontekście „rodzajem niemyślanej pozostałości [...] formalną naddeterminacją, która, 
w przypadku Freuda, będzie produkować powtórzenie, lub, w przypadku dekonstrukcji, może zamieszkiwać struktury językowe nieodpowiadające niczemu innemu" (Johnson 1994: 98)? Jeśli jedną z nazw na określenie siły tej niemyślanej pozostałości może być ironia, czyż odmieńczość nie może być kolejną? Wynikałoby stąd, że teoria queer stanowi miejsce, gdzie radykalna groźba ze strony ironii, którą to groźbę kultura heteronormatywna przenosi na figurę odmieńca, jest osobliwie zwracana przez odmieńców, którzy nie wyrzekają się już, ale akceptują swoją figuralną tożsamość jako ucieleśnienie figuralizacji, a więc również dysfiguracji, samej tożsamości. O ile polityczne interwencje mniejszości tożsamościowych - w tym również tych, którzy dążą do substancjalizacji tożsamości lesbijskich, gejowskich i biseksualnych - mogą przyjmować adekwatnie opozycyjną formę, oferując dominującemu porządkowi uspokajająco symetryczny, choć odwrócony, obraz jego własnej, pozornie spójnej, tożsamości, teoria queer stoi w opozycji do każdej takiej opozycyjnej logiki, a jej właściwe zadanie stanowi niekończące się wywłaszczanie wszelkiej właściwości. Odmieńczość nie może nigdy ustanowić autentycznej, substancjalnej tożsamości, a jedynie strukturalną pozycję determinowaną przez imperatyw figuracji, jako że luka, czy też rozbieżność, którą wprowadził porządek znaczącego, ożywia oraz zamieszkuje odmieńczość, tak jak zamieszkuje reprodukcyjny futuryzm. Z jedną jednak różnicą. Podczas gdy futuryzm zawsze antycypuje, na obraz Wyobrażeniowej przeszłości, spełnienie znaczenia, które zszyje tożsamość i zlikwiduje ową lukę, odmieńczość anuluje tożsamości, poprzez które doświadczamy siebie jako podmioty, obstając przy Realnym jouissance, z góry wykluczonym przez rzeczywistość społeczną oraz przez futuryzm, na którym się ona opiera.

Odmieńczość nie jest więc nigdy kwestią bycia czy stawania się, ale raczej ucieleśniania pozostałości Realnego w porządku Symbolicznym. Jedną z nazw nadanych przez Lacana tej nienazywalnej pozostałości jest jouissance, tłumaczona niekiedy jako „rozkosz", czyli wykroczenie poza zasadę przyjemności, poza rozróżnienie na przyjemność i ból, gwałtowne wyjście poza granice tożsamości, znaczenia i prawa. To wykroczenie, ku któremu pcha nas nieustannie siła popędów, może skutkować, o ile przyłączy się do konkretnego obiektu lub celu, okrzepnięciem tożsamości w fantazmat zaspokojenia lub spełnienia za pośrednictwem tego obiektu. Jednocześnie jednak jouissance uchyla takie fetyszystyczne inwestycje, burząc spoistość rzeczywistości społecznej opartą na Wyobrażeniowych identyfikacjach, na strukturach Symbolicznego prawa i na ojcowskiej metaforze imienia ${ }^{14}$. Dlatego też Lacan ma jeszcze inne określenie na tę nienazywalność, do której jouissance dałaby nam dostęp; jak pisze, "Za tym, co nazwane, kryje się nienazywalne. A ponieważ jest nienazywalne, ze wszystkimi skojarzeniami, jakie można temu słowu przypisać, jest ono pokrewne kwintesencjonalnej nienazywalności, czyli śmierci" (Lacan 1991: 211). ${ }^{29}$ Popęd śmierci realizuje się więc, choć w radykalnie różny sposób, w obydwu wersjach jouissance. O ile jouissance, jako fantazmatyczna ucieczka przed wpisaną w znaczenie alienacją, lokuje się w konkretnym obiekcie, na którym opiera się tożsamość, o tyle produkuje tożsamość jako umartwienie, odtwarzając to samo ograniczenie znaczenia, które w założeniu miała pomóc przezwyciężyć. O ile jednak powoduje rozerwanie tkanki Symbolicznej rzeczywistości, jaką znamy, rozpuszczając trwałość każdego obiektu, w tym także obiektu, za który obowiązkowo uznaje się podmiot, o tyle jouissance ewokuje popęd śmierci, który

14 Lacan zauważa, że Freud „nie cofa się przed stwierdzeniem, w Kulturze jako źródle cierpień, że zaspokojenie, jakie jouissance daje w pierwotnym stanie, nie ma nic wspólnego z tym, które daje w pośredniej, a nawet sublimowanej formie, do przyjęcia której zmusza ją cywilizacja" (Lacan 1992: 199-200). 
nieustannie trwa jako pustka wewnątrz podmiotu i pustka samego podmiotu, poza fantazmatem samospełnienia, poza zasadą przyjemności.

Z pierwszym z tych popędów śmierci wiąże się figura DZIECKA, wyrastająca z logiki powtórzenia, która ustanawia tożsamość poprzez identyfikację z przyszłością porządku społecznego. Z drugim wiąże się figura odmieńca, uosabiająca traumatyczne zetknięcie tego porządku z własnym nieuchronnym fiaskiem, zetknięcie z iluzją przyszłości, mającą na celu zaszyć konstytutywną ranę podporządkowania podmiotu znaczącemu, która paradoksalnie czyni go podmiotem i jednocześnie oddziela go od samego siebie. We wstępie do książki Homographesis napisałem, że znaczące "gej", rozumiane "jako figura na określenie tekstualności, retoryczności tego, co seksualne [...] desygnuje tę lukę albo niespójność, którą chciałby zawładnąć każdy dyskurs »seksualności« albo »tożsamości seksualnej «" (Edelman 1994: xv). W rozwinięciu tamtej tezy, sugeruję teraz, że odmieńcze seksualności, pozostając w ścisłym związku z wyłanianiem się podmiotu w Symbolicznym, znamionują owo miejsce luki, w którym Symboliczne staje w obliczu tego, czego jego dyskurs nie jest zdolny poznać i które jest zarazem miejscem jouissance, od którego nigdy nie może uciec. Jako figura tego, czego nie potrafi w pełni wyartykułować ani rozpoznać, queer może udzielać Symbolicznemu swego rodzaju koniecznego wsparcia poprzez fakt, że zdaje się nazywać to, co - jako Realne - pozostaje nienazywalne. Jednak wypieranie się tej figuralnej tożsamości, odzwierciedlające liberalną wiarę w abstrakcyjną uniwersalność podmiotu, jakkolwiek lepiej służy sprawie rozciągania praw na tych, którzy są ich pozbawieni, musi udzielać analogicznego wsparcia w postaci świadczenia na rzecz bezszwowej spoistości Symbolicznego, którego dominująca narracja wypiera tym samym żrącą moc odmieńczej ironii. Jeśli więc abiektalna różnica odmieńca funkcjonuje jako zabezpieczenie dla tożsamości, determinowanej przez normatywność, to queerowe wyrzeczenie się owej różnicy potwierdza jednostkową prawdę normatywności. Każde odrzucenie figuralnego statusu, do którego powoływani są - w odróżnieniu od wszystkich innych - odmieńcy, odtwarza triumf narracji jako alegoryzacji ironii jako logiki temporalności, która zawsze usiłuję ją "wyprostować", obwieszczając uniwersalność reprodukcyjnego futuryzmu. Takie odrzucenie, wbrew sobie, stanowi akt uległości względem prawa, które skutecznie narzuca politykę jako jedyną dostępną nam grę, pobierając przy tym haracz w postaci (hetero)normalizacji podmiotu, osiąganej - niezależnie od praktyk czy "orientacji" seksualnych - poprzez obowiązkowe wyrzeczenie się negującego przyszłość odmieńca.

Patrząc od wewnątrz tej struktury, można odnieść wrażenie, że Symboliczne może tylko wygrać; taki wniosek pomijałby jednak fakt, że jednocześnie może ono tylko przegrać. Rozdzielenie, na którym zasadza się podmiot, nie da się zbyć, a porządek sygnifikacyjny zawsze będzie stwarzał konieczność generowania takiego czy innego zbioru figur w odniesieniu do nadmiaru, który uniemożliwia osiągnięcie Jedni. W polu politycznym, którego granicą i horyzontem jest reprodukcyjny futuryzm, odmieńczość uosabia popęd śmierci, tę nieustępliwą jouissance, poprzez figurację uwikłania seksualności w bezsensownych parciach tego popędu. Dokonując deidealizacji metaforyki znaczenia, na której opiera się heteroreprodukcja, odmieńczość pokazuje, że seksualność jest nieuchronnie zabarwiona popędem poprzez swoją natrętną powtarzalność, swoje uporczywe negowanie teleologii, swój opór wobec ustalania znaczeń (chyba że znaczeniem tym jest właśnie niezgoda na ustalanie znaczeń) i wreszcie, nade wszystko, poprzez odrzucenie uduchowienia, które jest efektem mariażu z reprodukcyjnym futuryzmem. Chociaż odmieńczość, jako nazwa, może wzmacniać Symboliczny porządek nazywania, to jednak nazywa ona to, co opiera się, jako znaczące, wchłonięciu przez 
Wyobrażeniową tożsamość imienia. Pusta, powiązana z nadmiarem, nieredukowalna, desygnuje ona literę, element formalny, maszynerię bez życia odpowiedzialną za ożywianie "ducha" przyszłości. Jako taka, jako nazwa dla popędu śmierci, nieodmiennie przenikającego porządek Symboliczny, znamionuje ona również jouissance, zakazaną przez porządek Symboliczny, mimo iż zawsze w nim obecną.

Wyrzekając się naszej identyfikacji z tą negatywnością popędu, a tym samym naszej dezidentyfikacji z obietnicą przyszłości, ci z nas, którzy zamieszkują miejsce odmieńczości, mogą wprawdzie zrzucić z siebie ową odmieńczość i wkroczyć do właściwej sfery politycznej, ale jedynie za cenę przerzucenia figuralnego ciężaru odmieńczości na kogoś innego. Strukturalna pozycja odmieńczości oraz potrzeba jej wypełnienia nie znikają. Natomiast akceptując tę pozycję, przyjmując "prawdę" o naszej odmieńczej zdolności do figuralnego wskazania na rozbiórkę Symbolicznego, w tym także Symbolicznego podmiotu, moglibyśmy podjąć się niemożliwego zadania wyobrażenia sobie opozycyjnej postawy politycznej, uwolnionej od nakazu reprodukowania polityki sygnifikacji (tj. polityki zorientowanej na zamknięcie luki zainicjowanej przez znaczące), która może jedynie zaprowadzić nas z powrotem, poprzez DZIECKO, do polityki reprodukcji. Liberalny pogląd na społeczeństwo, który na pozór zapewnia miejsce odmieńcowi, jest równie daleki od poparcia dla odmieńczości oporu wobec reprodukcyjnego futuryzmu, a więc odmieńczości queeru, jak pogląd konserwatywnej prawicy. Podczas gdy środowiska prawicowe wyobrażają sobie eliminację odmieńców (albo potrzebę konfrontacji z ich istnieniem), lewica wyeliminowałaby odmieńczość, oświetlając ją chłodnym blaskiem rozumu w nadziei, że ukaże ją zaledwie jako jeden z rodzajów ekspresji seksualnej, wolny od wszechogarniającego pozorowania, od determinującej fantazmatycznej produkcji, za sprawą której odmieńczość może wydawać się zapowiedzią, i to nie tylko w oczach prawicy, rozbiórki porządku społecznego i jego gwiazdy przewodniej, DZIECKA. W ten sposób odmieńczość dla obydwu z nich oznacza wistocie nicość: dla prawicy - nicość w stanie nieustającej wojny z pozytywnością społeczeństwa obywatelskiego; dla lewicy - nic więcej jak tylko praktykę seksualną wymagającą demistyfikacji.

Jednak w tym miejscu rozum musi zawieść. Seksualność nie poddaje się demistyfikacji, ponieważ Symboliczne zaprzecza odmieńczemu, a seksualność i Symboliczne stają się tym, czym są, na mocy takich właśnie zaprzeczeń. Demistyfikacja odmieńczości, a w konsekwencji samej seksualności, demistyfikacja wpisana w liberalny racjonalizm, mogłaby osiągnąć swój cel, o ironio (ale przecież, jak dowodziłem wyżej, ironia zawsze cechuje teorię queer), jedynie idąc w poprzek zbiorowego fantazmatu, który dostarcza porządkowi społecznemu znaczenie, dzięki reprodukcyjnemu futuryzmowi. Gdyby potraktować go dosłownie, abstrakcyjny rozum liberalizmu, ocalając odmieńczość dla porządku społecznego, uchyliłby - podobnie jak odmieńczość - inwestycje, na których zasadza się porządek społeczny, likwidując libidinalne fantazmaty, które leżą u jego podstaw i które go podtrzymują. Poza horyzontem fantazmatu nie leży przecież ani prawo, ani rozum. W krainie zrealizowanej demistyfikacji, w tej neutralnej, demokratycznej dosłowności, która znamionuje futuryzm lewicy, napotkać można jedynie odmieńczy demontaż samego futuryzmu jako fantazmatu i derealizację porządku znaczenia, reprodukowanego przez futuryzm. Zachowując w polu widzenia nie cele, ale kres porządku społecznego, odmieńczość utrzymuje, że popęd ku temu kresowi, którego liberalizm nie dopuszcza nawet do myśli, jest nieodłącznym elementem strukturyzacji fantazji 
samego porządku społecznego. Tak więc sakralizacja DZIECKA pociąga za sobą konieczność ofiary z odmieńca.

Bernard Law, były kardynał Bostonu, błędnie (albo aż zbyt dobrze) pojmując zakres autorytetu, jakim obdarzyło go znaczące jego patronimicznego nazwiska ${ }^{15}$, potępił w 1996 roku propozycję regulacji prawnych, nadających homoseksualnym partnerom osób zatrudnionych przez władze miejskie, uprawnienia do świadczeń zdrowotnych. Oznajmił mianowicie, w akcie górnolotnej pobożności, że rozszerzenie dostępu do świadczeń zdrowotnych osłabiłoby znacząco więzy małżeńskie. Jego zdaniem: "Społeczeństwo ma szczególny interes w ochronie i wychowywaniu dzieci i winno otaczać je troską. Ponieważ małżeństwo pozostaje podstawowym i najlepszym środowiskiem dla rozwoju, edukacji i socjalizacji dzieci, państwo ma także szczególny interes w zachowaniu instytucji małżeństwa" (Slattery 1996: 68). Z tym zgubnym poparciem dla futuryzmu tak ślepo oddanego figurze DZIECKA, że usprawiedliwia odmowę świadczeń zdrowotnych dla dorosłych, na których wyrastają niektóre dzieci, Law użyczył swego głosu umartwiającej mantrze wspólnotowej jouissance, która polega na fetyszyzacji DZIECKA kosztem wszystkiego, co taka fetyszyzacja musi nieuchronnie skazać na odmieńczość. Jakieś siedem lat później, po tym, jak Law zrezygnował ze stanowiska z powodu niezapewnienia ochrony katolickim dzieciom przed księżmi pedofilami, papież Jan Paweł II powrócił do tematu, potępiając uznawane przez państwo związki jednopłciowe jako parodię autentycznych rodzin, jako oparte raczej na "indywidualnym egoizmie”, niż na prawdziwej miłości. W uzasadnieniu stwierdził: „Taka karykatura rodziny nie ma przyszłości i nie może zapewnić przyszłości żadnemu społeczeństwu" (Jan Paweł II 2003). Odmieńcy muszą odpowiedzieć na gwałtowność tych ciągłych prowokacji, nie tylko domagając się równego prawa do prerogatyw porządku społecznego, nie tylko deklarując swoją zdolność do wzmacniania spójności i integralności tego porządku, ale także wypowiadając na głos to, co kardynał Law, papież i cały porządek Symboliczny, który reprezentują, i tak słyszą w obliczu każdej ekspresji lub manifestacji odmieńczej seksualności: pieprzyć porządek społeczny i DZIECKO, w imię którego jesteśmy zbiorowo terroryzowani; pieprzyć Annie; pieprzyć prawa i Bernardów Law; pieprzyć całą sieć Symbolicznych relacji i przyszłość, która służy jej za pretekst.

Może chcemy wierzyć, że dzięki cierpliwości, dzięki pracy, dzięki hojnym datkom dla grup nacisku lub ofiarnej działalności w grupach aktywistycznych lub znacznej dozie uczoności w prawie i wyborczego wyrafinowania, przyszłość zapewni nam miejsce przy politycznym stole bez potrzeby rezygnowania z miejsc, których szukamy w łóżku, w barze, w saunie. Jednak w tej przyszłości nie ma żadnych odmieńców, ponieważ odmieńcy nie mogą mieć żadnej przyszłości, mogą jedynie głosić złą nowinę, że w ogóle nie może być żadnej przyszłości; że przyszłość, tak jak pojmuje ją hymn Annie na cześć nadziei lepszego "Jutra”, jest "zawsze / o jeden dzień przed nami”. Niczym kochankowie na greckiej urnie z wiersza Keatsa ${ }^{16}$, zawsze "bliscy celu" zjednoczenia, którego jednak nigdy nie dostąpią, jesteśmy niewolnikami przyszłości nieustannie odraczanej przez sam czas, zmuszeni podążać za marzeniem o dniu, kiedy dziś i jutro staną się jednością. Ta przyszłość to nic innego jak dziecinne mrzonki, które odradzają się każdego dnia na nowo, aby przesłonić grób, ziejący spod martwej litery, wabiąc nas i wplątują w pajęczą sieć rzeczywistości. Ci, na których porządek spo-

15 Law oznacza „prawo”. [Przyp. tłum.]

16 Odwołanie do znanego wiersza Johna Keatsa "Ode on a Grecian Urn” (Oda do urny greckiej). [Przyp. tłum.] 
łeczny projektuje swój popęd śmierci, sprowadzeni do roli odmieńców, zajmują bez wątpienia właściwą pozycję, aby rozpoznać strukturujący fantazmat, który ich tak definiuje. Ponadto zajmują właściwą pozycję, aby rozpoznać nieredukowalność owego fantazmatu oraz koszt interpretowania go jako zależnego od logiki społecznej organizacji jako takiej. Zgoda na tę figuralną identyfikację z demontażem tożsamości, czyli równocześnie z dezartykulacją społecznej i Symbolicznej formy, może być równie dobrze opisana słowami Johna Brenkmana jako "politycznie autodestrukcyjna"17. Jednak polityka (jako społeczne kształtowanie rzeczywistości) oraz "ja” (jako proteza podtrzymująca przyszłość dla figuralnego DZIECKA) są tym, co odmieńczość, znów jako figura, musi niszczyć musi o tyle, o ile "ja" jest agentem reprodukcyjnego futuryzmu, a polityka środkiem do propagowania go jako porządku rzeczywistości społecznej. Być może, jak świadczy o tym uwaga, którą Lacan poświęca Antygonie w Seminarium VII, polityczne samozniszczenie jest z natury wpisane w jedyny akt godny tego miana: akt oporu wobec zniewolenia przez przyszłość w imię posiadania życia.

Jeżeli przeznaczeniem odmieńca jest figuracja przeznaczenia, które zrywa nić przyszłości, jeśli jouissance przynależna odmieńczej (nie)tożsamości, ta żrąca rozkosz, unicestwia fetyszystyczną jouissance, która działa na rzecz konsolidacji tożsamości, pozwalając rzeczywistości zakrzepnąć wokół jej rytualnej reprodukcji, to wówczas jedyny opozycyjny status, do którego mogłaby nas kiedykolwiek doprowadzić nasza odmieńczość, polegałby na poważnym potraktowaniu popędu śmierci, do figuracji którego jesteśmy powoływani, i na trwaniu na stanowisku - wbrew kultowi DZIECKA i politycznemu porządkowi, który wymusza - że nie jesteśmy, jak ujął to Guy Hocquenghem, „znaczącym czegoś, co mogłoby stać się nową formą »organizacji społecznej«, że nie planujemy nowej polityki, lepszego społeczeństwa, bardziej świetlanego jutra, ponieważ wszystkie te fantazje reprodukują przeszłość i przenoszą ją na przyszłość. Zamiast tego naszym wyborem jest nie wybierać DZIECKA, jako dyscyplinującego obrazu Wyobrażeniowej przeszłości lub miejsca projektowanej identyfikacji z zawsze niemożliwą przyszłością. Odmieńczość, którą proponujemy, jest - słowami Hocquenghema - „nieświadoma przemijania pokoleń jako etapów na drodze do lepszego życia. Nic jej nie wiadomo o »teraźniejszym poświęceniu dla dobra przyszłych pokoleń« [...] wiadomo jej natomiast, że cywilizacja jako taka jest śmiertelna" (Hocquenghem 1993: 138, 147). Więcej: cieszy się tą śmiertelnością jako negacją wszystkiego, co definiuje się moralistycznie jako „pro-life”. To my musimy pogrzebać podmiot w przypominającym grób wydrążeniu znaczącego, wypowiadając wreszcie słowa, za które i tak zostaniemy potępieni, bez względu na to, czy je wymówimy, czy nie: że to my jesteśmy orędownikami aborcji; że DZIECKO jako emblemat przyszłości musi umrzeć; że przyszłość jest jedynie powtórzeniem, równie śmiercionośnym jak przeszłość. Nasza odmieńczość (nie) ma nic do zaoferowania Symbolicznemu, które tę nicość odtrąca, oprócz uporczywego przypominania o dręczącym nadmiarze, który owa nicość implikuje, przypominania o negatywności, która przeszywa fantazmatyczny ekran przyszłości, rozsadzając narracyjną temporalność za pomocą nieodmiennie wybuchowej mocy ironii. Tym, co jest najbardziej odmieńcze w nas i mimo nas, jest ta gotowość, aby trwać nieprzechodnio - trwać na stanowisku, że przyszłość kończy się właśnie tutaj.

17 Zob. odpowiedź Johna Brenkmana na pierwotną wersję niniejszego argumentu: Brenkman 2002: 177. 


\section{Bibliografia}

Adorno, Teodor W. 1986. Dialektyka negatywna. Tłum. S. Krzemienia-Ojaka. Warszawa: PWN.

Ariès, Philippe. 2011. Historia dzieciństwa. Tłum. M. Ochab. Warszawa: Aletheia.

Barnard, Suzanne. 2002. The Tongues of Angels: Feminine Structure and Other Jouissance. W: (red.) Barnard, Suzanne i Fink, Bruce. Reading Seminar XX: Lacan's Major Work on Love, Knowledge, and Feminine Sexuality. Albany: State University of New York Press.

Bennet, James. 1997. Clinton, in Ad, Lifts Image of Parent. „New York Times" 4.03.1997. http://www.nytimes.com/1997/03/04/us/clinton-in-ads-lifts-image-of-parent.html; dostęp: 9.01.2017.

Berlant, Lauren. 1997. The Queen of America Goes to Washington City. Durham: Duke University Press.

Brenkman, John. 2002. Queer Post-Politics. W: „Narrative” 10, s. 174-180.

Butler, Judith. 1993. Bodies That Matter: On the Discursive Limits of "Sex". New York: Routledge.

Charnin, Martin. 1977. (słowa). Strouse, Charles (muzyka). „Tomorrow” z musicalu Annie.

Edelman, Lee. 1994. Homographesis: Essays in Gay Literary and Cultural Theory. New York: Routledge.

Eliot, T.S. 1988. Ziemia jałowa. W: Eliot, T.S. Poezje wybrane. Tłum. A. Piotrowski, Michał Sprusiński et al. Warszawa: Instytut Wydawniczy PAX.

G.O.P. Hypocrisy. 2003. "New York Times" 25.04.2003.

Hocquenghem, Guy. 1993. Homosexual Desire. Durham: Duke University Press.

James, Phyllis D. 2006. Ludzkie dzieci. Tłum. M. Gębicka-Frąc. Warszawa: Wydawnictwo Mag.

Jan Paweł II. 2003. Znak nadziei dla Kościoła i świata. Rozważanie przed modlitwa Anioł Pański 26 i 2003 r. http://papiez.wiara.pl/doc/377268.Znak-nadziei-dla-Kosciola-i-swiata; dostęp: 9.01.2017.

Johnson, Barbara. 1987. A World of Difference. Baltimore, London: Johns Hopkins University Press. - - -. 1994. The Wake of Deconstruction. Cambridge: Basil Blackwell.

Kincaid, James. 1992. Child Loving: The Erotic Child and Victorian Culture. New York: Routledge. - - -. 1998. Erotic Innocence: The Culture of Child Molesting. Durham: Duke University Press.

Kosofsky Sedgwick, Eve. 1990. Epistemology of the Closet, Berkeley: University of California Press. Lacan, Jacques. 1974. Télévision. Paris: Éditions du Seuil.

- - -. 1991. Le Seminaire, livre XVII, L'envers de la psychanalyse. Paris: Éditions du Seuil.

- - -. 1991. The Seminar of Jacques Lacan. Book II: The Ego in Freud's Theory and in the Technique of Psychoanalysis, 1954-1955. New York: Norton.

- - -. 1992. The Seminar of Jacques Lacan. Book VII: The Ethics of Psychoanalysis, 1959-1960. New York: Norton. 
Man, Paul de. 1996. Aesthetic Ideology. Minneapolis: University of Minnesota Press.

Pope Warns Against 'Inauthentic' Version of Family 26.01.2003. http://fox59.com/2016/11/06/popewarns-against-walls-ahead-of-us-election; dostęp: 9.01.2017.

Sack, Kevin. 1997. Officials Look for Any Links in Bombings in Atlanta. "New York Times" 2.02.1997.

Shalala, Donna. 1998. Women's Movement. „HHS.gov Archive” 17.07.1998. https://archive.hhs.gov/news/speeches/sene.html; dostęp: 9.01.2017.

Slattery, Ryan. 1996. Cardinal Law Urges Menino to Veto Bill Giving Benefits to City Workers' Partners. „Boston Sunday Globe” 17.03.1996.

Stone, Lawrence. 1977. The Family, Sex, and Marriage in England, 1500-1800. New York: Harper and Row.

Wangerin, Walter Jr. 1993. O Brave New World, That Has No People In't! The Children of Men. „New York Times Book Review" 28.03.1993.

Wildmon, Donald. 1997. Hope '97 Tour to Counter Pro-Homosexual Philosophy in American Culture, American Family Association Action Alert, 25.02.1997. http://www.cfinwed.com/headline.htm; dostęp: 9.01.2017. 


\title{
Bartleby i Michael K., czyli dlaczego tylko mężczyzna może stać się innym?
}

\section{Joanna Bednarek}

badaczka niezależna

\begin{abstract}
[Artkuł ukazał się wcześniej na łamach InterAliów w sekcji artykuły bieżące, tutaj.]
Wiele już napisano na temat stworzonej przez Hermana Melville'a postaci Bartleby'ego - najczęściej interpretując stynne "wolatbym nie" jako różnie pojmowana formę politycznego lub pre-politycznego oporu. Tę lawinę tekstów zapoczątkowat, o czym się czasem zapomina, esej Gilles'a Deleuze'a "Bartleby albo formuta”, którego centralnym motywem jest nie opór, ale stawanie-się-innym: proces oddalania się od dominującego, większościowego wzorca męskiej, europejskiej, kapitalistycznej i edypalnej tożsamości. Procesowi temu może jednak podlegać tylko wspomniany większościowy podmiot: inny, dzięki któremu możliwe jest stawanie się, petni wytącznie funkcje pomocnicza czy instrumentalna: w przypadku tekstu Melville'a, to bezimienny narrator, a nie Bartleby, jest jego prawdziwym bohaterem. Stawanie się jest więc przygoda zarezerwowana dla podmiotu większościowego. Deleuze wydaje się jednak nie zdawać sobie sprawy z tego ograniczenia. Tekst Coetzee'ego ukazuje natomiast, na przykładzie skazanej na porażkę relacji między tytułowym bohaterem a próbujacym go "zrozumieć" lekarzem, asymetrię dwóch terminów stawania się i podporządkowanie innego, a tym samym dekonstruuje hierarchię zawarta w pojęciu stawania się.
\end{abstract}

Słowa kluczowe: stawanie się, Deleuze i Guattari, Bartleby, Coetzee

Postać Bartleby'ego, stworzona w 1853 roku przez Hermana Melville'a, doczekała się pod koniec XX wieku niezwykłej sławy: poświęcono jej szereg interpretacji filozoficznych, najczęściej skupiających się na słynnej formule "wolałbym nie" jako różnie pojmowanej formie politycznego bądź pre-politycznego oporu wobec władzy. Tą drogą podążają w swoich odczytaniach opowiadania Melville'a - czy raczej nieco węższych próbach zinterpretowania samego motywu Bartleby'ego - Giorgio Agamben, Slavoj Žižek czy Antonio Negri i Michael Hardt'. U źródeł wspomnianej popularności Bartleby'ego znajduje się jednak odczytanie znacznie mniej redukcyjne, bliższe tekstowi Melville'a esej Gilles'a Deleuze'a „Bartleby albo formuła” z 1989 roku.

Deleuze, zamiast ograniczać się do samej postaci Bartleby'ego, podkreśla fakt, że o dynamice opowiadania stanowią relacje między ekscentrycznym kopistą a zatrudniającym go adwokatem - pierwszoosobowym narratorem tekstu. Narrator, którego „normalność” i reprezentatywność jako „uniwersalnego" (męskiego, białego, obdarzonego władzą ekonomiczną i symboliczną) podmiotu zostaje podkreślona na samym początku tekstu Melville'a, zawiera z Bartlebym rodzaj paktu, owocującego jego oddaleniem się od symbolicznego centrum. Nie tylko od początku traktuje Bartleby'ego inaczej niż pozostałych pracowników, ale nawet (gdy ten uparcie powtarza wolałbym nie w odpowiedzi na służbowe polecenia), usiłuje go zrozumieć, a potem udzielić mu pomocy (zamiast, jak postąpiłoby większość pracodawców, po prostu wyrzucić go z pracy). Czyni tak, mimo że -

1 Zob. G. Agamben, Bartleby, czyli o przypadkowości (2009); M. Hardt, A. Negri, Imperium (2005), s. 221-222; S. Žižek, Notes Towards a Politics of Bartleby (2006); Jacques Ranciere przedstawia natomiast, wychodząc od tekstu Deleuze'a, krytykę deleuzjańskiej koncepcji powiązania polityki i estetyki; zob. J. Ranciere, Deleuze, Bartleby, and the Literary Formula (2004). 